\title{
Tenderness Indicator
}

National Cancer Institute

\section{Source}

National Cancer Institute. Tenderness Indicator. NCI Thesaurus. Code C127775.

An indicator as to whether the subject has symptoms of tenderness. 